\title{
Land use and seasonal effects on a Mediterranean soil bacterial community
}

\author{
D. Francioli ${ }^{1}$, J. Ascher ${ }^{2,3}$, M.T. Ceccherini ${ }^{2 *} \&$ G. Pietramellara ${ }^{2}$ \\ ${ }^{1}$ Department Bodenökologie/Soil Ecology, Helmholtz-Zentrum für Umweltforschung GmbH - UFZ, Theodor-Lieser Str. 4, \\ 06120 Halle (Saale), Germany. ${ }^{2}$ Dipartimento di Scienze delle Produzioni Vegetali Agroalimentari e dell'Ambiente, Università \\ degli Studi di Firenze, Piazzale delle Cascine 28, 50144 Florence, Italy. ${ }^{3}$ Institute of Microbiology, University of Innsbruck, \\ Technikerstrasse 25d, 6020 Innsbruck, Austria. "Corresponding author: mariateresa.ceccherini@unifi.it
}

\begin{abstract}
To evaluate the effects of management practices and seasons on a soil bacterial community and the composition of ammonia-oxidizing bacteria (AOB), molecular screenings were compared among Mediterranean (Sardinia) soils with different plant covers and different agricultural practices, namely cork oak forest, tilled/non-tilled vineyard, hay crop and pasture. We compared the fingerprints from both independent replicates and pooled samples to ascertain the best approach for studying the environmental effects on bacterial composition. The soil microbial biomass, which was estimated from the amounts of extracted soil dsDNA, was 2 to 3 folds higher in the spring than in the autumn; in the spring, it was negatively correlated with the intensity of land use. A 16S rDNA DGGE experiment confirmed that both the land use and season markedly affect the composition of the soil bacterial community. Tilled vineyard soil exhibited the lowest similarities in community structures, suggesting that tillage induced the most marked disturbance among the tested land management methods. Distinct AOB populations were found for each type of land use; among these types, the cork oak forest proved to be a protective habitat for AOB against environmental changes. Our results suggest that the comparative community level and group-specific fingerprinting enabled an accurate evaluation of multiple factors in soil bacterial structures when performed with both independent and pooled replicates.
\end{abstract}

Keywords: Microbial biomass, PCR-DGGE, land management, seasonal shifts, ammonia oxidizing bacteria, pooled soil samples 


\section{Introduction}

Soil is a highly complex biological system that is influenced by correlated physical-chemical and environmental parameters, and it presents a varied habitat for a diverse range of soil microorganisms (Pietramellara et al., 2002; Campos et al., 2012). Soil microbes are closely linked to soil properties, and their diversity is critical for the maintenance of soil health because they are involved in principal soil functions (Parkinson \& Coleman, 1991) and soil tilth and structure (Tisdall, 1991). Recently, the intensified demand for food and biofuel production has led to the conversion of forests and grasslands into intensively managed lands by using agricultural practices such as tillage, fertilization and pesticide application. These practices aim to maximize crop production in the short-term, impairing the ability of soils to provide other essential ecosystem services; consequently, they reduce soil fertility and sustainability in the long-term (Liiri et al., 2012), often coupled with a decline in soil biodiversity. The current perspective suggests that shifts in plant community composition may affect soil organic carbon (SOC) dynamics (Jin et al., 2010), and studies have indicated that the varied effects of forest conversion on soil $\mathrm{C}$ are related to the soil type, crops and pasture and management practices (Nunes et al., 2012). The impact of anthropogenic activities (land use) on soil characteristics such as the water content, soil texture, temperature, $\mathrm{pH}$ and soil nutrient levels with consequences for microbial communities is well documented (Noe et al., 2012). In addition, several studies have been undertaken to compare microbial communities among soils with different fertility or land use histories (Yao et al., 2000) or different management regimes (Shaheen et al., 2010). Microorganisms, which are sensitive indicators of the status of an ecosystem, can lose their resilience to ecosystem disturbances and become unable to perform their normal nutrient cycling and soil structure maintenance processes. Nevertheless, the precise mechanisms of these changes and their effects have not been fully explored, and an improved knowledge of the general relation between soil properties and soil biota under different land use types is needed to understand the consequences of future changes (Birkhofer et al., 2012).

The application of molecular techniques to study microbial soil ecology has increased in recent years, and the use of 16S rRNA genes as biomarkers for genetic fingerprinting (e.g., Denaturing Gradient Gel Electrophoresis, DGGE and Restriction Fragment Length Polymorphism, RFLP) has become a standard for screening microbial communities (Bacteria, Archaea and Fungi) in terms of richness and evenness. DGGE is a well-established, simple and rapid technique (Nannipieri et al., 2003) that is routinely used in microbial ecology (Marzorati et al., 2008), even if it is restricted to the most dominant populations of a complex microbial community (Ascher et al., 2010). Its strength lies in its ability to monitor changes in community structures vs. keystone species (i.e., actinomycetes, $\mathrm{AOB}$ and $\mathrm{N}_{2}$ fixers) in response to changes in environmental parameters over space and time (Noe et al., 2012). In fact, an alternative approach to studying how different management regimes impact bacterial communities is to target a phylogenetically constrained bacterial group associated with a certain function, such as ammoniaoxidizing bacteria (AOB). These bacteria are key players in the nitrogen cycle, and they are responsible for the majority of the ammonia oxidation in arable soils. These bacteria represent a small proportion of the total microbial biomass in soil; however, because of their sensitivity and their importance in nitrogen cycling, they have been suggested as model organisms in soil microbial ecology (Kowalchuk \& Stephen, 2001) and they have frequently been used as indicators of soil perturbations caused by herbicides, metals, temperature, precipitation, nitrogen deposition and agronomic practices (Nyberg et al., 2006; Ceccherini et al., 2007); AOB have also been studied here for this reason. The present work is based on five soils that are characterized by different land uses and collected from Sardinia (Italy), which are employed as representatives of a typical Mediterranean site. In the past, these soils 
were covered by cork oak forests (Quercus suber), but today, they are treated with different land management approaches such as the tilled vineyard, non-tilled vineyard, hay crop and grassland. We hypothesized that soil microorganisms would be influenced by land use changes. We performed community-level and groupspecific screenings (DGGE) to assess the bacterial composition as a function of the land management (tilled vineyard, non-tilled vineyard, pasture, hay crop and cork oak forest) and season (spring and autumn). The pooling of independent replicates was also considered.

\section{Materials and Methods}

\subsection{Study site and soil sampling}

The experimental area is located in Berchidda (Sardinia, Italy; $40^{\circ} 46^{\prime} \mathrm{N}, 9^{\circ} 10^{\prime} \mathrm{E}$ ). The altitude ranges from $275 \mathrm{~m}$ to 300 meters above sea level. The soil developed from hydromorphic and granitic parent material with a loamy sand texture, and it is classified as Typic Dystroxerepts according to the USDA Soil Taxonomy (Soil Survey Staff, 2006).

The climate is a mesothermal Mediterranean, subhumid phytoclimatic belt with a mean annual rainfall of 862 $\mathrm{mm}$ and a mean temperature of $13.8^{\circ} \mathrm{C}$.

Five sites with different agricultural management strategies located inside an area of $1.5 \mathrm{~km}^{2}$ were selected; their physico-chemical soil properties are described in Lagomarsino et al. (2011).

A tilled vineyard (TV) was established in 1994 with the vine cultivar Vermentino. The soil $\mathrm{pH}$ was 5.3. The soil was tilled up to $40 \mathrm{~cm}$ deep in February, May and July. In January, organic fertilization with "Fertil" (12.5\% organic $\mathrm{N}, 40 \%$ organic $\mathrm{C}$ and $70 \%$ organic matter) was applied $\left(2 \mathrm{q} \mathrm{ha}^{-1}\right)$. The pruning residues were removed from the field.

A no-till vineyard (NV) was established in 1985 with the vine cultivar Vermentino. The soil $\mathrm{pH}$ was 6.4 .
No tillage was performed in this soil. Foliar mineral fertilization was applied in April (5 $\left.\mathrm{q} \mathrm{ha}^{-1}\right)$. Pruning residues were cut, chopped and left on the soil surface at the end of January and in June. Drip irrigation was provided for up to $100 \mathrm{~mm}$ to restore part of the crop evaporation-transpiration in June and July. The grass cover was freely self-sown.

The hay crop (HC), pasture (PA) and cork oak forest (CO) were established 30 years ago. HC and PA soils were cultivated following a 6-year rotation period. The PA had a rotation scheme of 5 years as PA and 1 year as a HC. The HC had a complementary scheme of 5 years as a HC and 1 year as a PA. The HC was planted with common oats, Italian ryegrass and clover. During the $\mathrm{HC}$ phase, the soil was plowed and harrowed before seeding. The $\mathrm{HC}$ was pastured with sheep and cattle (30 units ha-1). The soil $\mathrm{pH}$ was 5.4. Mineral fertilizer with $18-46\left(\mathrm{~N}-\mathrm{P}_{2} \mathrm{O}_{5}\right)$ proportions was applied in January $\left(2 \mathrm{q} \mathrm{ha}^{-1}\right)$. The PA was covered with spontaneous herbaceous vegetation, primarily Hordeum leporinum, Trifolium michelianum, $T$. subterraneum and $T$. resupinatum. Fertilization was performed with potassium sulfate in January $\left(1 \mathrm{q} \mathrm{ha}^{-1}\right)$ and the plot was pastured with sheep (30 units $\left.\mathrm{ha}^{-1}\right)$; the soil $\mathrm{pH}$ was 5.2 . The $\mathrm{CO}$ soil was dominated by shrub cover and scattered Quercus suber $\mathrm{L}$. trees. The cork harvest occurs every 11 years; the soil $\mathrm{pH}$ was 5.8 .

In May and November of 2007, from five sampling plots were chosen randomly from each of the different land management schemes (TV, NV, CO, $\mathrm{HC}$ and PA) (Figure 1). For each of these plots, five soil cores $(0-20 \mathrm{~cm}$ depth) were taken and pooled together. Thus, the five soil plots were independent replicates of each land management method. The soil samples were packed in sterile plastic bags, placed on ice and transported to the laboratory. The soil samples were sieved $(2 \mathrm{~mm})$ to remove fine roots and large organic debris and stored at $-20^{\circ} \mathrm{C}$ until DNA extraction. 


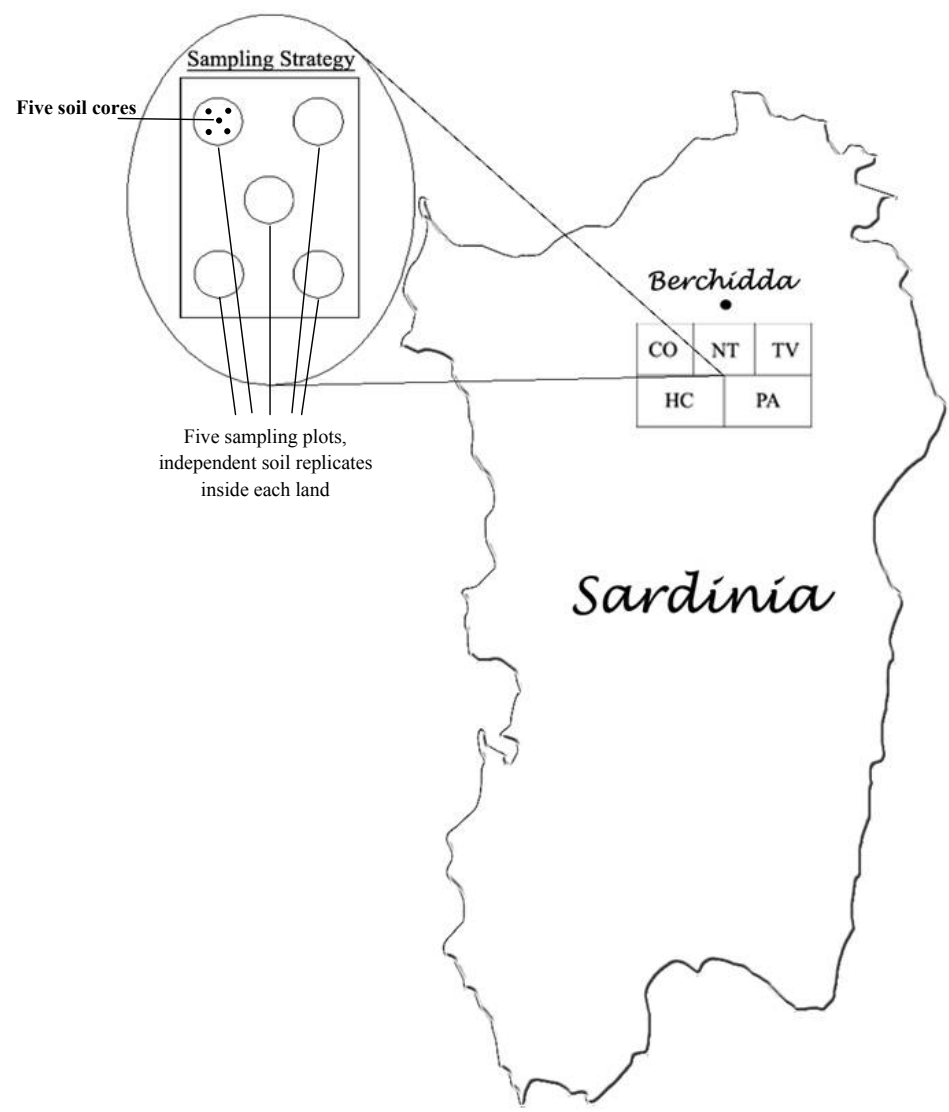

Figure 1. Maps and sampling strategy/land use types: non-tilled vineyard (NV), cork oak forest (CO), pasture (PA), hay crop (HC) and tilled vineyard (TV).

\subsection{Total DNA extraction}

Total DNA was extracted in triplicates from $0.5 \mathrm{~g}$ of bulk soil (fresh weight) by bead-beating method (Fast DNA Kit for Soil BIO101, Qbiogen) in accordance with the manufacturer's instructions.

The soil DNA was quantified by fluorimetric measurements in a Hoefer DyNA Quant 200 fluorimeter and Hoechst 33258 dye solution (Amersham Pharmacia Biotech) that specifically binds to double-stranded DNA (dsDNA), and the yields were reported in $\mu \mathrm{g} \mathrm{g}^{-1}$ to indicate the soil microbial biomass (Marstorp et al., 2000; Hartmann et al., 2006).

The molecular weight of DNA and its fragment length distribution were assessed by agarose gel electrophoresis (1x Tris acetate EDTA buffer; $100 \mathrm{~V}$; $60 \mathrm{~min}$ ) after staining (1:10000) with $10 \mathrm{mg} \mathrm{ml}^{-1} \mathrm{EtBr}$ and comparing with a DNA mass ladder (Fermentas, 80-20000 bp). 


\subsection{Community level profiling of soil bacteria}

The 16S rRNA genes from total extracted DNA were amplified by polymerase chain reaction (PCR) with GC-clamped, eubacterial-specific primers GC968f/ UNI1401r (Nübel et al., 1996) under the following reaction conditions: $94{ }^{\circ} \mathrm{C}$ for $90 \mathrm{~s}$ followed by 33 cycles at $95{ }^{\circ} \mathrm{C}$ for $20 \mathrm{~s}, 56^{\circ} \mathrm{C}$ for $30 \mathrm{~s}, 72{ }^{\circ} \mathrm{C}$ for $45 \mathrm{~s}$, and a final extension step at $72{ }^{\circ} \mathrm{C}$ for $7 \mathrm{~min}$. One hundred ng of amplicons (473 bp) was analyzed by DGGE on a $6 \%$ polyacrylamide gel (acrylamide/bisacrylamide $37.5: 1 ; 20 \mathrm{~cm}$ x $20 \mathrm{~cm} ; 1 \mathrm{~mm}$ ) with a urea-formamide denaturing gradient of $46-56 \%(100 \%$ denaturant contains $7 \mathrm{M}$ urea and $40 \%$ formamide) at $60{ }^{\circ} \mathrm{C}, 70 \mathrm{~V}$ for $16 \mathrm{~h}$ by using the DCode system (Bio-Rad, Hercules, CA, USA) as reported by Agnelli et al. (2004).

The DGGE fingerprints were visualized by UV light gel transillumination $(254 / 497 \mathrm{~nm})$ after staining for $2 \mathrm{~h}$ in SybrGreen I (1:10 000; FMC Bio Products, Rockland, ME, USA), and digital images were captured with a Gel Doc System (Bio-Rad).

A DGGE was performed on five independent replicates for each land management method to assess differences in bacterial community distributions. Because of the expected high level of bacterial heterogeneity within each treated field, the replicates were pooled together at the amplicon level to obtain a representative sample for each land management method; this approach was applied to assess shifts more accurately in the bacterial community structure as a function of the land management type and season.

\subsection{The group-specific profiling of ammonia-oxidizing bacteria}

The total extracted DNA (40 ng) of each soil sample was amplified with an amoA-1F-GC and amoA-2R primer set specific to ammonia-oxidizing bacteria (AOB) (Rotthauwe et al., 1997). The thermal cycling conditions were as follows: $94{ }^{\circ} \mathrm{C}$ for $5 \mathrm{~min}$ followed by 35 cycles of $94{ }^{\circ} \mathrm{C}$ for $45 \mathrm{~s}, 50{ }^{\circ} \mathrm{C}$ for $30 \mathrm{~s}$ and elongation at $72{ }^{\circ} \mathrm{C}$ for $1 \mathrm{~min}$. A GC clamp

\section{(5'-CGCGCGCGGCGGGCGGGGCGGGGGCACGG}

GGGG-3') as described by Muyzer et al., (1997) was added to the 5 ' end of the forward primer to stabilize the melting behavior of the DNA fragments during DGGE analysis. Amplicons (491 bp, 100 ng) were analyzed by DGGE under the same conditions as reported for bacterial community DGGE.

\subsection{Statistical analysis}

The yields of extracted total DNA were reported in $\mu \mathrm{g}$ DNA g ${ }^{-1}$ soil (mean values $\mathrm{n}=5 \pm$ standard deviation) and differences between the mean values were evaluated by a one-way analysis of variance (ANOVA: $p \leq 0.05$ ) followed by a Duncan post-hoc test (alpha $=0.05$ ).

Similarities between the DGGE profiles were determined by UPGMA (unweighted pair group method with arithmetic mean) cluster analyses based on Dice similarity coefficients (Dice 1945) in Quantity One 4.1 software (Bio-Rad).

Furthermore, the DGGE patterns were analyzed in terms of the number of bands in each fingerprint, and this quantitative descriptor was used to estimate the apparent bacterial richness (Sigler et al., 2004; Ascher et al., 2010). The phylotype richness was then subjected to a two-way ANOVA to assess if both the land management type and season had a significant influence on bacterial richness. A Duncan post-hoc test (alpha = 0.05 ) was used to perform multiple comparisons.

\section{Results}

\subsection{Microbial biomass}

In May, the soil microbial biomass ( $\mu \mathrm{g}$ DNA $\mathrm{g}^{-1}$ soil) depended on the land management, as reflected by marked variations in the DNA yields. In fact, the highest DNA yield was obtained from the undisturbed cork oak forest, followed by pasture, non-tilled vineyard, hay crop and tilled vineyard; the tilled vineyard was the 
most intense among all tested agricultural practices. In the autumn, the microbial biomass did not vary between treatments and was significantly lower (2-3-folds) than it was in May (Table 1). The DNA extracted from each soil type in November showed high molecular weights $(>20 \mathrm{~kb})$ and a higher fragmentation was observed in May, which could be explained by the higher microbial activity with consequently higher microbial turnover in the spring than in the autumn (data not shown).

Table 1. The average yields ( $\mu \mathrm{g} \mathrm{g}^{-1}$ soil) of total extracted DNA from each type of soil examined in the spring (May) and autumn (November). Numbers in parentheses represent standard deviations $(n=5)$. Different letters indicate significant differences $(p>0.05)$.

\begin{tabular}{lll}
\hline Soils & $\begin{array}{l}\text { Spring } \\
\text { DNA } \mu \mathrm{g} \mathrm{g}^{-1} \text { of soil }\end{array}$ & $\begin{array}{l}\text { Autumn } \\
\text { DNA } \mu \mathrm{g} \mathrm{g}^{-1} \text { of soil }\end{array}$ \\
\hline Cork oak forest & $9.7 \pm(3.0) \mathrm{a}$ & $1.9 \pm(1.0) \mathrm{a}$ \\
\hline Pasture & $7.2 \pm(1.7) \mathrm{b}$ & $2.1 \pm(1.5) \mathrm{a}$ \\
\hline $\begin{array}{l}\text { Non-tilled } \\
\text { vineyard }\end{array}$ & $5.4 \pm(0.9) \mathrm{bc}$ & $2.3 \pm(2.7) \mathrm{a}$ \\
\hline Hay crop & $5.2 \pm(0.7) \mathrm{bc}$ & $2.3 \pm(1.2) \mathrm{a}$ \\
\hline Tilled vineyard & $4.5 \pm(1.0) \mathrm{c}$ & $1.9 \pm(0.9) \mathrm{a}$ \\
\hline
\end{tabular}

\subsection{The biodiversity of the soil bacterial community}

The molecular fingerprints of the bacterial community generated distinct patterns for each soil type and sampling period as a function of different land uses (CO, PA, HC, NV or TV) and seasons (spring or autumn).

The DGGE assay was performed with independent replicates, and it yielded high spatial heterogeneity as expected within each study site for both sampling times. In the spring, the similarities in the bacterial communities with different land management types ranged from $55-90 \%$ (Table 2), with the highest and lowest similarities found in NV (75-90\%) and CO (55-65\%), respectively. In the autumn, the highest and lowest similarities were found in $\mathrm{HC}$ (60-80\%) and PA (40-65\%), respectively.

Table 2. Spatial shifts between replicates of soil bacterial communities, reflecting soil heterogeneity as a function of the land use and season. Similarities (Dice index-based UPGMA analysis) were obtained from a DGGE test of five independent replicates.

\begin{tabular}{lll}
\hline Type of soil & Spring & Autumn \\
\hline Tilled vineyard & $60-70 \%$ & $60-70 \%$ \\
\hline Non-tilled vineyard & $75-90 \%$ & $65-70 \%$ \\
\hline Cork oak forest & $55-65 \%$ & $55-65 \%$ \\
\hline Hay crop & $70-80 \%$ & $60-80 \%$ \\
\hline Pasture & $65-80 \%$ & $40-65 \%$ \\
\hline
\end{tabular}

The observed spatial shift reflected the heterogeneity of the soil bacteria, which led us to homogenize the replicate-amplicons in two samples for each land management type and to perform a second DGGE to highlight the effects of land use and season on the bacterial structures. A cluster analysis of these DGGE patterns generated three distinct clusters (51\% similarity), reflecting marked differences in the response of soil bacterial communities to different land management types and seasonal changes (Figure 2). 


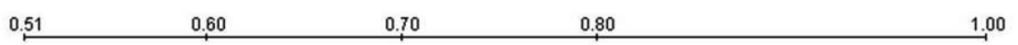

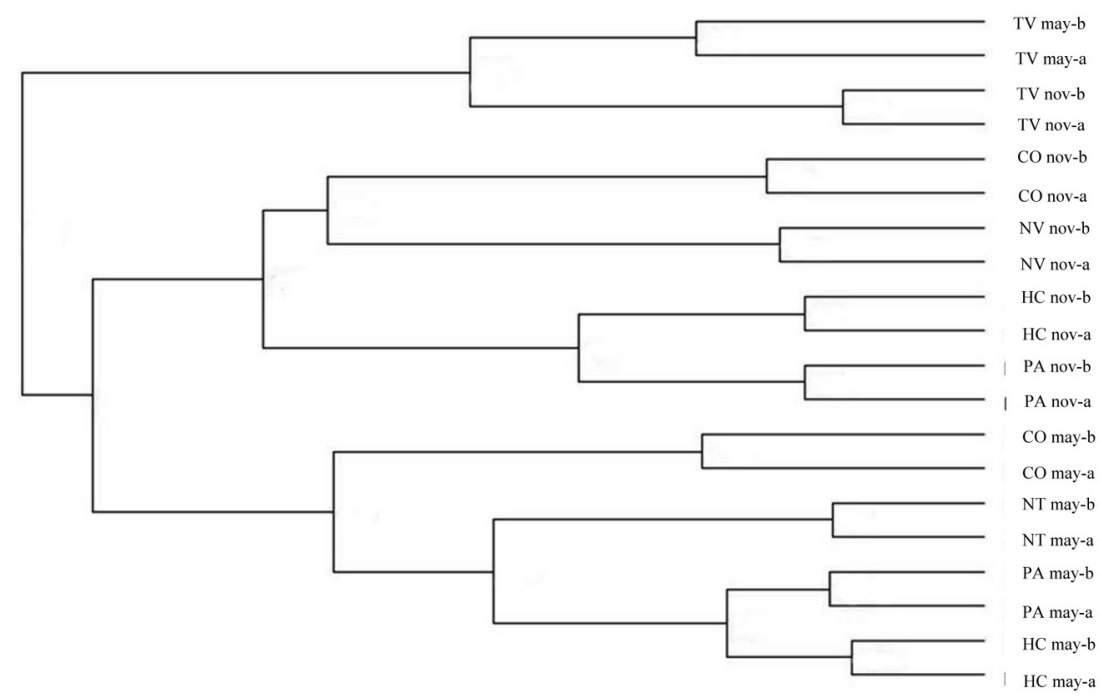

Figure 2. Similarities in the eubacterial communities within the five different soils of the study area, namely nontilled vineyard (NV), cork oak forest (CO), pasture (PA), hay crop (HC) and tilled vineyard (TV). May is referred to as spring and Nov is referred to as autumn. The letters a and b indicate the replicates. Dendrograms were created by Dice similarity index-based UPGMA cluster analysis in Quantity One (Biorad) software.

Cluster 1 included all the samples collected in May with the exception of the tilled vineyard; cluster 2 contained all the soil samples collected in November with the exception of the tilled vineyard. Cluster 3 was made up of tilled vineyard soils taken at both sampling times, indicating that this intense land management style had a greater influence than the seasonal effects on the bacterial composition. Clusters 1 and 2 grouped together with a similarity of $54 \%$, indicating that climatic factors have a great influence on prokaryotic biodiversity. In addition, the effect of less invasive methods relative to tillage use was remarkable; in fact, each soil type grouped together in cluster 1 and cluster 2 with $67 \%$ and $63 \%$ similarities, respectively. An exception was reported for the hay crop (HC) and grassland soils (PA) that had a high index of similarity in both clusters, with $87 \%$ in the spring and $79 \%$ in the autumn. This finding could be explained by the same greenery coverage, primarily oat grass, that characterized these soils.

\subsection{Biodiversity at the level of ammonia-oxidizing bacteria}

The dendrogram constructed for ammonia-oxidizing bacteria (Figure 3) showed the land management and season effects ( $38 \%$ similarity). In fact, each land use and sampling time determined a distinct AOB population; one exception was found for the $\mathrm{CO}$, in which a high similarity (77\%) was observed between May and 
November. This finding indicated that $\mathrm{AOB}$ were very stable in response to seasonal changes and were clustered apart from all other soil samples with 38\% similarity. Another cluster was found for $\mathrm{HC}$, and the seasonal shift was expressed at a $50 \%$ similarity. A third cluster contained all other samples at both seasons (59\%-41\%), indicating a high heterogeneity in the AOB because of the given environmental factors. The phylotype richness of AOB exhibited differences between the different land management types and the two sampling times.

$\begin{array}{lllllll}0.38 & 0.50 & 0.60 & 0.70 & 0.80 & 0.90 & 1.00\end{array}$

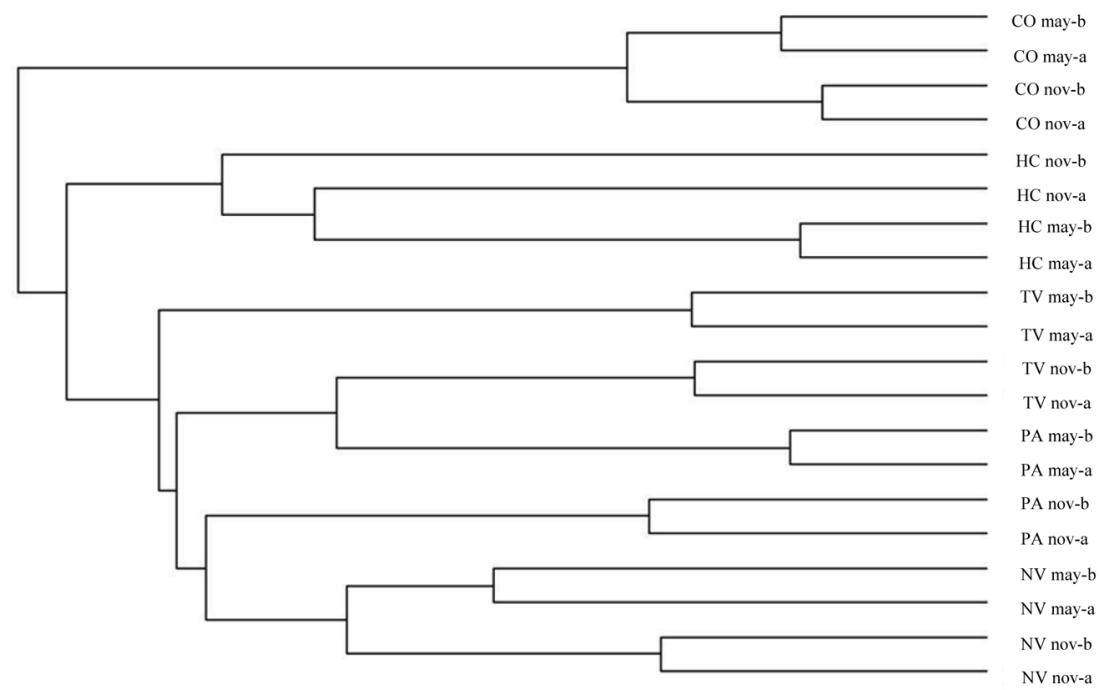

Figure 3. Similarities in the ammonia-oxidizing bacterial communities within the five different soils of the study area, namely non-tilled vineyard (NV), cork oak forest (CO), pasture (PA), hay crop (HC) and tilled vineyard (TV). May is referred to as spring and Nov is referred to as autumn. The letters a and b indicate the replicates. Dendrograms were created by Dice similarity index-based UPGMA cluster analysis in Quantity One (Biorad) software.

\section{Discussion}

We monitored changes in the composition of the eubacterial community and the ammonia-oxidizing population of a Mediterranean soil ecosystem (in Sardinia, Italy). The studied area was characterized by changes from a natural condition (cork oak forest) to an intensive agricultural soil use (tilled vineyard) through intermediate steps such as grassland, pasture and non-tilled vineyard (Lumini et al., 2010). Our results showed that different land management types and seasons strongly influenced the dynamics of both the microbial biomass and the composition of the eubacterial community. In the spring, the microbial biomass, as expressed as soil dsDNA, was ranked forest $>$ pasture $>$ non-tilled vineyards $>$ hay crop $>$ tilled vineyards (Table 1); this trend was also observed by 
Lagomarsino et al., (2011) who estimated the soil microbial biomass carbon (MBC) by fumigation extraction method in the same soils. These findings supported the idea that the microbial biomass carbon (MBC) and DNA content are strongly correlated and confirmed the high comparability of these indicators for estimating the sizes of soil microbial biomasses (Marstorp et al., 2000; Hartmann et al., 2006; Gangneux et al., 2011; Ascher et al., 2012). The overall highest quantity of soil DNA extracted from the cork oak forest was also correlated with the highest TOC and organic matter values found in this soil (Lagomarsino et al., 2011); this finding could be explained by the large organic input derived from the vegetation, such as litter, root exudates and dead roots, which provides a great source of organic carbon favoring microbial growth. After all, the larger observed size of the soil microbial biomass in (undisturbed) forest soil than in (disturbed) agricultural soils is well documented (Zornoza et al., 2009; García-Orenes et al., 2010). The microbial biomass was significantly lower in the autumn (2-3-folds) than in the spring, and it was similar for all soils. This seasonal reduction in the soil microbial biomass can be attributed to marked differences in temperature and soil moisture (Fterich et al., 2001; Noe et al., 2012) between these seasons, and these factors are more favorable for microbial growth in the spring than in the autumn.

The DGGE results of the five independent replicates confirmed the heterogeneity of microbial diversity within each soil site as found by other authors (Franklin et al., 2003; Zornoza et al., 2009), but the DGGE performed by pooling the five independent replicates to obtain homogeneous samples for each soil management type was able to "reduce" the previous spatial shifts that could mask differences in community structures, and thereby improved the sensitivity of the fingerprinting to evaluate the impact of multiple factors (land management type vs. season, in this case) on soil bacteria. Moreover, this modus operandi allowed for the analysis of all samples of different soil management types on a single DGGE run for a direct comparison, reducing technical biases.
The seasons were clearly distinguished for all land use types except tilled vineyard in two clusters (spring vs. autumn), indicating the importance of climatic conditions in determining soil bacterial structures when non-intense management was employed. The differences induced by land management were observed inside these two seasonal clusters. In fact, the soil vegetation cover can influence soil physicochemical properties such as the $\mathrm{pH}$, organic matter content, soil structure and microclimate (Kara et al., 2008). In addition, litter and root exudates supply C to soil microorganisms (Yang \& Crowley 2000). Changes in any of these factors can have consequences for the composition of microbial communities. For these reasons, the perennial vegetation of the cork oak forest and non-tilled vineyards exerted different effects on the microbial community in comparison with the annual vegetation of the pasture and hay crop. Moreover, the hay crop and pasture showed similarities during both sampling periods (87\% in May and 79\% in November), likely because of the similar land management of these soils, which had been cultivated following a short rotation period. In accordance with these findings, Buckley \& Schmidt (2001) used 16S rRNA oligonucleotide probes to quantify the abundance of rRNA from major phylogenetic lineages. They reported similar microbial community structures in soils with similar long-term histories of agricultural management, despite differences in recent land-use practices and above-ground community compositions. In addition, the similar $\mathrm{pH}$ values of these soils (5.65.4) could be determinants for the high similarity in bacterial structures, as noted in other works (Andreetta et al., 2012; Ascher et al., 2012; Noe et al., 2012). However, the bacterial phylotype richness did not seem to be correlated with the observed seasonal shift in biomass because similar bacterial phylotype richness was found during both seasons. The seasonal effect became evident when comparing the cluster analysis and the phylotype richness. In fact, the number of dominant bacteria did not change between the spring and autumn, and the cluster analysis revealed a marked difference in the community composition between 
May and November, suggesting a seasonal shift in the dominant bacterial members of the soil types. In the case of the tilled vineyard, the similarity index between May and November was rather high (77\%), and the number of bands was almost the same during both seasons, indicating that the dominant bacteria in these soils did not change markedly. However, the prokaryotic community in the tilled vineyard at both sampling times formed a unique group that clustered apart from the others at a $51 \%$ similarity level, indicating a more pronounced impact from intensive land management than the season on bacterial composition.

This study was further explored by examining the amoA functional gene of the $\beta$-subgroup in Proteobacteria, and this gene promptly responded to natural and anthropogenic environmental changes. A cluster analysis of the DGGE profile revealed distinct AOB compositions that were manifestly caused by management practices, which was consistent with the recent literature (Yu et al., 2010; Wertz et al., 2011). The similarity in AOB detected in the spring and autumn for each soil type, except for the cork oak forest, was very low, and this finding could be ascribed to AOB sensitivity to differences in temperature and soil moisture during the two seasons and to anthropogenic practices (Szukics et al., 2010; Noe et al., 2012). However, the similarity detected during the spring and autumn in the cork oak forest was higher (77\%), indicating a moderate seasonal effect on the AOB population.

Our results suggest that a stable undisturbed environment, such as a pristine forest soil in which human activity has not taken place for a long time, could represent a suitable habitat for the growth and development of AOB populations, but these bacteria could also become $\mathrm{K}$ strategists and react differently to environmental factors within a short period, depending on the given management practices. We provide evidence that an additional DGGE with pooled replicates enables a more accurate evaluation of multiple factor (land management, season) effects on the soil bacterial community structure (relative to a DGGE trial that employs independent replicates to assess the spatial heterogeneity of a given study site) that could be masked by the natural heterogeneity of soil bacteria.

\section{Conclusions}

The studied site was characterized by an ecological progression from a natural cork oak forest to intensive agricultural tillage through intermediate steps as grassland, pasture and non-tilled vineyard. Our results confirmed that different land uses and seasons strongly influence the dynamics of the soil microflora; in fact, the dsDNA, which expressed the microbial biomass, was higher in the forest environment than it was in the pasture, non-tilled vineyards, hay crop and tilled vineyards. This result is attributable to the large organic inputs (litter, root exudates and dead roots) in forest soils that provide a great source of organic carbon, favoring microbial growth. In the autumn, the microbial biomass was significantly (two or three folds) lower than it was in the spring, and it was similar for all soils. These results can be explained by the more favorable conditions (temperature and soil moisture) that occur in the spring than in the autumn for microbial growth. The resulting cluster analyses indicated the importance of climatic conditions in determining soil bacterial structures when nonintense management types were applied. Differences caused by land management styles were observed within the spring and autumn clusters. Interestingly, the tilled vineyard formed a unique group at both sampling times that clustered apart from the others, showing a more pronounced effect from the intensive land management than the seasons on bacterial composition. The ammonia oxidizer composition was clearly affected by management practices.

The approach of grouping the five independent replicates to produce a homogeneous sample for each soil management type allowed for reduced spatial 
shifts in the microbial composition, which could be used to evaluate the impact of multiple factors on one DGGE experiment alone.

\section{Acknowledgments}

This study was supported by the FISR (Fondo integrativo Speciale per la ricerca), "Ministero dell'Economia e delle Finanze dell'Istruzione, Università e Ricerca, dell'Ambiente della Tutela del Territorio, delle Politiche Agricole e Forestali”, Italy.

\section{References}

Agnelli, A., Ascher, J., Corti, G., Ceccherini, M.T., Nannipieri, P., Pietramellara, G. 2004. Distribution of microbial communities in a forest soil profile investigated by microbial biomass, soil respiration and DGGE of total and extracellular DNA. Soil Biology \& Biochemistry, 36, 859-868.

Andreetta, A., Macci, C., Ceccherini, M.T., Cecchini, G., Masciandaro, G., Pietramellara, G., Carnicelli, S. 2012. Microbial dynamics in Mediterranean Moder humus. Biology and Fertility of Soils. 48, 259-270.

Ascher, J., Ceccherini, M.T., Chroňáková, A., Jirout, J., Borgogni, F., Elhottová, D., Šimek, M., Pietramellara, G. 2010. Evaluation of the denaturing gradient gel electrophoresis (DGGE) apparatus as a parameter influencing soil microbial community fingerprinting. World Journal of Microbiology and Biotechnology, 26, 1721-1726.

Ascher, J., Sartori, G., Graefe, U., Thornton, B., Ceccherini, M.T., Pietramellara, G., Egli, M. 2012. Are humus forms, mesofauna and microflora in subalpine forest soils sensitive to thermal conditions? Biology and Fertility of Soils. 48, 709-725.
Birkhofer, K., Schöning, I., Alt, F., Herold, N., Klarner, B. 2012. General relationships between abiotic soil properties and soil biota across spatial scales and different land-use types. PLoS ONE 7, 43292.

Buckley, D.H., Schmidt, T.M. 2001. The structure of microbial communities in soil and the lasting impact of cultivation. Microbial Ecology, 42, 11-21.

Campos, A.C., Etchevers, J.B., Oleschko, K.L. , Hidalgo, C.M. 2012. Soil Microbial biomass and nitrogen mineralization rates along an altitudinal gradient on the Cofre de Perote volcano (Mexico): the importance of landscape position and land use. Land Degrad. Develop. DOI: 10.1002/ldr.2185

Ceccherini, M.T., Ascher, J., Pietramellara, G., Mocali, S., Viti, C. \& Nannipieri P. 2007. The effect of pharmaceutical waste-fungal biomass, treated to degrade DNA, on the composition of eubacterial and ammonia oxidizing populations of soil. Biology and Fertility of Soils. 44, 299-306

Dice LR. 1945. Measures of the amount of ecologic association between species. Ecology. 26, 297-302.

Fterich, A., Mahdhi, M., Mars, M. 2011. The effects of Acacia Tortilis subsp. Raddiana, soil texture and soil depth on soil microbial and biochemical characteristics in arid zones of Tunisia. Land Management and Degradation, DOI: 10.1002/ ldr.1154.

Franklin, R.B., Mills, A.L. 2003. Multi-scale variation in spatial heterogeneity for microbial community structure in an eastern Virginia agricultural field. FEMS Microbiology Ecology. 44, 335-346.

Gangneux, C., Akpa-Vinceslas, M., Sauvage, H., Desaire, S., Houot, S., Laval, K. 2011. Fungal, bacterial and plant dsDNA contributions to soil total DNA extracted from silty soils under different farming practices: Relationships with chloroformlabile carbon. Soil Biology \& Biochemistry. 43, 431-437. 
García-Orenes, F., Guerrero, C., Roldán, A., MataixSolera, J., Cerdà, A., Campoy, M., Zornoza, R., Bárcenas, G., Caravaca, F. 2010. Soil microbial biomass and activity under different agricultural management systems in a semiarid Mediterranean agroecosystem. Soil and Tillage Research. 109, $110-115$.

Hartmann, M., Fliessbach, A., Oberholzer, HR., Widmer, F. 2006. Ranking the magnitude of crop and farming system effects on soil microbial biomass and genetic structure of bacterial communities. FEMS Microbiology Ecology. 57, 378-388.

Jin, H., Sun, O.J., Liu, J. 2010. Changes in soil microbial biomass and community structure with addition of contrasting types of plant litter in a semiarid grassland ecosystem. Journal of Plant Ecology. 3, 209-217.

Kara, Ö., Bolat, İ. Çakıroğlu, K., Öztürk, M. 2008. Plant canopy effects on litter accumulation and soil microbial biomass in two temperate forests. Biology and Fertility of Soils. 45,193-198.

Kowalchuk, G.A., Stephen, J.R. 2001. Ammoniaoxidizing bacteria: A model for molecular microbial ecology. Annual Review of Microbiology. 55, 485-529.

Lagomarsino, A., Benedetti, A., Marinari, S., Pompili, L., Moscatelli, M.C., Roggero, P.P., Lai, R., Ledda, L., Grego, S. 2011. Soil organic $\mathrm{C}$ variability and microbial functions in a Mediterranean agro-forest ecosystem. Biology and Fertility of Soils. 47, 283-291.

Liiri, M., Hasa, M., Haimi, J., Setala, H. 2012. History of land-use intensity can modify the relationship between functional complexity of the soil fauna and soil ecosystem services - A microcosm study. Applied Soil Ecology. 55, 53-61.
Lumini, E., Orgiazzi, A., Borriello, R., Bonfante, P., Bianciotto, V. 2010. Disclosing arbuscular mycorrhizal fungal biodiversity in soil through a land-use gradient using a pyrosequencing approach. Environmental Microbiology. 12, 2165-79.

Marstorp, H., Guan, X., Gong, P. 2000. Relationship between dsDNA, chloroform labile $\mathrm{C}$ and ergosterol in soils of different organic matter contents and $\mathrm{pH}$. Soil Biology \& Biochemistry. 32, 879-882.

Marzorati, M., Wittebolle, L., Boon, N., Daffonchio, D., Verstraete, W. 2008. How to get more out of molecular fingerprints: practical tools for microbial ecology. Environmental Microbiology. 10, 1571-1581.

Muyzer, G., Brinkhoff, T., Nübel, U., Santegoeds, C., Schafer, H., Wawer, C. 1997. Denaturing gradient gel electrophoresis (DGGE) in microbial ecology. In 'Molecular Microbial Ecology Manual, vol 344. (Eds ADL Akkermans, JD Van Elsas, De Bruijn, FJ Kluwer) (Academic Publishers: Dordrecht, The Netherlands) pp 1-27.

Nannipieri, P., Ascher, J., Ceccherini, M.T., Landi, L., Pietramellara, G., Renella, G. 2003. Microbial diversity and soil functions. European Journal of Soil Science. 54, 655-670.

Noe, L., Ascher, J., Ceccherini, M.T., Abril, A., Pietramellara, G. 2012. Molecular discrimination of bacteria (organic versus mineral soil layers) of dry woodlands of Argentina. Journal of Arid Environments,.85, 18-26.

Nübel, U., Engelen, B., Felske, A., Snaidr, A., Wieshuber, A., Amann, R., Ludwig, W., Backhaus, H. 1996. Sequence heterogeneities of genes encoding 16S rRNAs in Paenibacillus polymyxa detected by temperature gradient gel electrophoresis. Journal of Bacteriology. 178, 5636-5643. 
Nunes, J.S., Araujo, A.S.F., Nunes, L.A.P.L., Lima, L.M., Carneiro, R.F.V., Salviano, A.A.C., Tsai, S.M. 2012. Impact of land degradation on soil microbial biomass and activity in Northeast Brazil. Pedosphere, 22, 88-95.

Nyberg, K., Schnurer, A., Sundh, I., Jarvis, A., Hallin, S. 2006. Ammonia-oxidizing communities in agricultural soil incubated with organic waste residues. Biology and Fertility of Soils. 42, 315323

Parkinson, D., Coleman, D.C. 1991. Microbial communities, activities, and biomass. Agriculture, Ecosystems and Environment. 34, 3-33.

Pietramellara, G., Ascher, J., Ceccherini, M.T., Renella, G.C. 2002. Soil as a biological system. Annals of Microbiology. 52, 119-131.

Rotthauwe, J.H., Witzel, K.P., Liesack, W. 1997. The ammonia monooxygenase structural gene amoA as a functional marker: molecular fine-scale analysis of natural ammonia-oxidizing populations. Applied Environmental Microbiology. 63, 4704-471.

Shaheen, A., Naeem, M.A., Jilani, G., Shafiq, M. 2010. Integrated soil management in eroded land augments the crop yield and water-use efficiency. Acta Agriculturae Scandinavica Section B-Soil and Plant Science. 60, 274-282.

Soil Survey Staff 2006 Keys to Soil Taxonomy, 10th edition. US Department of Agriculture, Natural Resource Conservation Service

Sigler, W.V., Miniaci, C., Zeyer, J. 2004. Electrophoresis time impacts the denaturing gradient gel electrophoresis-based assessment of bacterial community structure. Journal of Microbiological Methods. 57, 17-22.

Szukics, U., Abell, G.C.J., Hödl, V., Mitter, B., Sessitsch, A., Hackl, E., Zechmeister-Boltenstern, S. 2010. Nitrifiers and denitrifiers respond rapidly to changed moisture and increasing temperature in a pristine forest soil. FEMS Microbiology Ecology. 72, 395-406.

Tisdall, J.M. 1991. Fungal hyphae and structural stability of soil. Australian Journal of Soil Research. 29, 729-743.

Wertz, S., Leigh, A.K.K., Grayston, S.J. 2011. Effects of long-term fertilization of forest soils on potential nitrification and on the abundance and community structure of ammonia oxidizers and nitrite oxidizers. FEMS Microbiology Ecology. 79,142-154.

Yang, C.H., Crowley, D.E. 2000. Rhizosphere microbial community structure in relation to root location and plant iron nutritional status. Applied Environmental Microbiology. 66, 345-351.

Yao, H., He, Z., Wilson, M.J., Campbell, C.D. 2000. Microbial biomass and community structure in a sequence of soils with increasing fertility and changing land use. Microbial Ecology. 40, 223237.

Yu, W.T., Xu, Y.G., Bi, M.L., Ma, Q., Zhou, H. 2010. Activity and composition of ammonia-oxidizing bacteria in an aquic brown soil as influenced by land use and fertilization. Pedosphere. 20, 789798.

Zornoza, R., Guerrero, C., Mataix-Solera, J., Scow, K.M., Arcenegui, V.J., Mataix-Beneyto, V. 2009. Changes in soil microbial community structure following the abandonment of agricultural terraces in mountainous areas of Eastern Spain. Applied Soil Ecology. 42, 315-323. 